\title{
Need for application of remote sensing technologies for development of agro-industrial complex
}

\author{
Elena Denisova* and Victoria Silova \\ Federal Research Center "Agroecology of the Russian Academy of Sciences", 400062, Volgograd, \\ Russian Federation
}

\begin{abstract}
Agricultural production has influence on all areas of social activity. In the modern context of agro-industrial complex development, ensuring the economic security of the country directly depends on availability and suitability of the land, the degree of developed land. Land is a source of food, profits, economic independence of each region, the state of which depends on continuous monitoring and application of advanced technologies. The purpose of the work is to determine quantitative and qualitative state of arable land in the Volgograd region, the level of spread of degradation processes based on digital and remote sensing technologies, as well as the creation of graphic documentation necessary for making economic forecasts and plans. Availability and use of arable land in 33 municipal districts of the Volgograd region are unequal. The largest number of arable land is 5,4 \% in Pallasovsky district, the smallest one is $1,3 \%$ in Sredneakhtubinsky district. The differentiation of the region into five natural-agricultural and three land-assessment areas is caused by the necessity to register soil fertility during agricultural use of arable land, both in irrigated arable land and non-irrigated. According to the statistical records the irrigated arable land is used only in the amount of $20 \% .88 \%$ of the region's territory is subject to degradation processes. The land with the cadastral number 34:21:040003:67and an area of 137,2 hectares is characterized by a high degree of territory blurring, degradation of soil cover, which led to the loss of humus and removal to the upper layers of the soil of salt marshes. Remote sensing techniques allow obtaining reliable information and making social and economic forecasts in large areas in a short period of time.
\end{abstract}

\section{Introduction}

The sustainable and stable development of the agro-industrial complex directly depends on the quality of land resources, which are not only a means of obtaining products and raw materials for production, but also a multifaceted natural complex that determines social and economic growth of each region. Deteriorating climatic conditions, increasing anthropogenic load on land are reducing land productivity and lead to degradation and

\footnotetext{
* Corresponding author: denisov.00@mail.ru
} 
disposal from agricultural use, also have a negative impact within the borders of the entire agricultural landscape. This situation requires application of new, high technologies during land monitoring and analysis, as well as the development of an integrated approach for the rational management of agro-industrial production [1].

The land fund of the Volgograd region is strategically important due to the unique natural and geographical conditions, opportunities to get various types of agricultural products [2]. The region belongs to the most developed territories, and further expansion of agricultural land area is almost impossible. With the total area of 11287,0 thousand hectares, almost $80 \%$ accounts for agricultural land, of which $67 \%$ is arable land, $29,8 \%$ is pastures, the rest of the land is less than $20,0 \%$.

The quality of land resources ensures the stable functioning and stability of the agricultural landscape and determines the structure of land use and the degree of erosion load. Ensuring the reproduction of agricultural land, namely arable land, is the guarantor for the effective management of land resources in all sectors of the agro-industrial complex and to be the top priority of the state.

\section{Research instruments and methods}

Remote sensing techniques are important because they allow to study the state of the land in a very short time and to map a large area of territory with high granularity. These methods make it possible not only to monitor the current situation but also forecast for effective land management.

Among the existing methods of assessment on land degradation and preservation of land quality the most interesting are those that provide a forecast of changes occurring on agricultural land, with a real variation of external and internal factors that determine such changes.

The scientists such as I.A. Mirtova and Yu.E. Patsyna [3], X. Li, X. Liu and L. Yu [4], H. Erol and F. Akdeniz [5] and others dealt with the issues of studying the structure of economic land use and its condition applied space imagery.

Modern land quality research methods are based on aerospace research methods in conjunction with geoinformation technologies and computer modeling.

The source of remote sensing data for the assessment of arable land is multispectral images obtained from Worldview 3, Landsat-8 and others satellites and data from global digital terrain models.

Geoinformation systems are widely used to solve various problems in the field of arable land degradation. Thus, the QGIS 3.12 software system is used to assess the current state and analyze arable land. Using geoinformation methods of spatial information evaluation and construction of vector contours allows calculating automatically such parameters as area, length of perimeter and other geomorphological values of objects in the table of attributes [6, 7].

To evaluate the state of arable land and determine the degree of its degradation geoinformation software complexes QGIS 6.8 and SASPlanet are used, by which processing, analysis and visualization of data are carried out, a terrain profile is built, thematic maps are created and others.

\section{Results and discussions}

The primary task of the agro-industrial complex of the Volgograd region is to obtain stable yields while maintaining the quality and amount of productive arable land, especially in conditions of arid climate and lack of moisture. Availability of 33 municipal districts of the 
Volgograd region located within two soil varieties - chernozem and chestnut, as well as five natural-agricultural areas plays an important role in the distribution of arable land and the nature of its use. The largest number of arable land is in Pallasovsky 5,4 \%, Staropoltavsky 4,2 \%, Mikhailovsky, Oktyabrsky, Novoanninsky, Uryupinsky, Kalachevsky and Nikolaev municipal districts vary from $3,9 \%$ to $3,4 \%$.

The current territorial division differentiates the Volgograd region by three landassessment areas, each of which is characterized by an average geology score of soil fertility. Novoanninsky and Uryupinsky municipal districts are classified as the I landassessment area with an average soil score of 85, the rest areas are included into the III land-assessment area, where the average geometric mean score is 50 . According to the agricultural landscape zoning, the areas with largest prevailing of arable land are located in the desert-steppe interstream and desert-steppe ancient-sea area with a humus content of 2$3 \%$ and a humus horizon capacity of $25-30 \mathrm{~cm}$.

Getting high stable yields and growing of certain types of agricultural products are impossible without irrigation due to natural features of the Volgograd region. The Volgograd region ranks $2^{\text {-nd }}$ among the regions of the Russian Federation in production of melons and gourds, and $1^{\text {-st }}$ in the land under cultivation for food melons and gourds or $36,6 \%$ of the total melon production area in the Russian Federation.

The area of irrigated land decreased by 187,5 thousand hectares since 1991 and it accounts to 181,5 thousand hectares (4,3 \% of the total amount of arable land). However, according to the results of the agricultural census in 2016, only 40,4 thousand hectares are really used in the Volgograd region. The largest number of irrigated land is located in Gorodishchensky municipal district - 19,06 thousand hectares and in Nikolaevsky municipal district - 5,5 thousand hectares or 13,5 \%. Irrigation on irrigated land of the region is carried out mainly by sprinkling, as well as by surface and furrow irrigation. Nowadays the drip irrigation is more often used. When irrigating agricultural land, it is necessary to take into account many factors - climatic, soil, geomorphological, hydrogeological, biological, and economic and others.

Difficult natural conditions, anthropogenic effect on the environment, irrigation amelioration load up arable land leading to its degradation, destruction, loss of soil fertility and, as a result, agricultural land transactions. The agro-industrial complex suffers huge losses.

Remote sensing technologies allow tracking the economic use of land, identifying unused and useless land, as well as occurring degradation processes that lead to agricultural land transactions $[8,9]$.

The rapid erosion advancing is a severe problem for the economic development of the region. The analysis of the erosion advancing processes revealed the areas that were subject to erosion - Jirnovsky (96,3 \%), Kamyshinsky (83,1 \%) and Kotovsky municipal districts (80,2\%). Salinization processes are common within the boundaries of Leninsky (36,46 \%), Nikolaevsky (36,19\%), Pallasovsky (56,1 \%), Sredneakhtubinsky municipal districts (40,2\%).

The following municipal districts are subject to soil blowing: Alekseevsky (80,5 \%), Elansky (85,6 \%), Kikvidzensky (84,8 \%), Kumylzhensky (83,9 \%), Nekhaevsky (83,5 \%), Novoanninsky (84,8 \%), Novonikolaevsky (82,2 \%) and Uryupinsky (84,7 \%). Salinization processes are common within the borders of Leninsky (36,46\%), Nikolaev (36,19\%), Pallasovsky (56,1\%), Sredneakhtubinsky municipal districts (40,2 \%).

The research shows that each of the municipal districts of the Volgograd region is subject to certain phenomena (natural, social, anthropogenic), which have a restraining effect on the economic growth and stability of the agro-industrial complex. 


\section{Conclusion}

The cartographic method and aerospace monitoring allow evaluating and preventing development of destructive effects. Application of remote sensing technologies and assessment of its role for development of the agro-industrial complex of the region are shown within the borders of Sovetsky rural settlement of Oktyabrsky municipal district of the Volgograd region. The analysis of the spatial patterns of land has shown that the territory is compact $(1,03)$, the minimum elevation is $95,2 \mathrm{~m}$, the maximum one is $146,2 \mathrm{~m}$, the height difference is $51 \mathrm{~m}$. Within the boundaries of the settlement with a perimeter of $349,41 \mathrm{~km} \mathrm{10,06}$ thousand hectares of arable land is used. Arable contours have an irregular configuration, the smallest area of the circuit is 3,77 hectares, the largest one is 556,95 hectares, the average field size is 135,9 hectares.

The territory is cut by gullies and ravines that cause erosion processes in particular water and wind erosion. The agricultural landscape of the settlement consists of the same type of arable land; there are no natural forage lands. Insufficient field-protective afforestation of the territory also promotes to erosion advancing. The main forms of erosion are deflation, salinization and salinity.

The development of erosion processes in the settlement is facilitated by a high degree of plowing of the territory. Of the total area of the settlement (13,3 thousand hectares), the specific gravity of arable land accounts to 75,6 \%. Fragmentation of borders, shallow contour and low afforestation of arable land cause erosion advancing, lead to decreasing of soil fertility and finally result in decreasing of yield and gross agricultural production (Fig. $1)$.

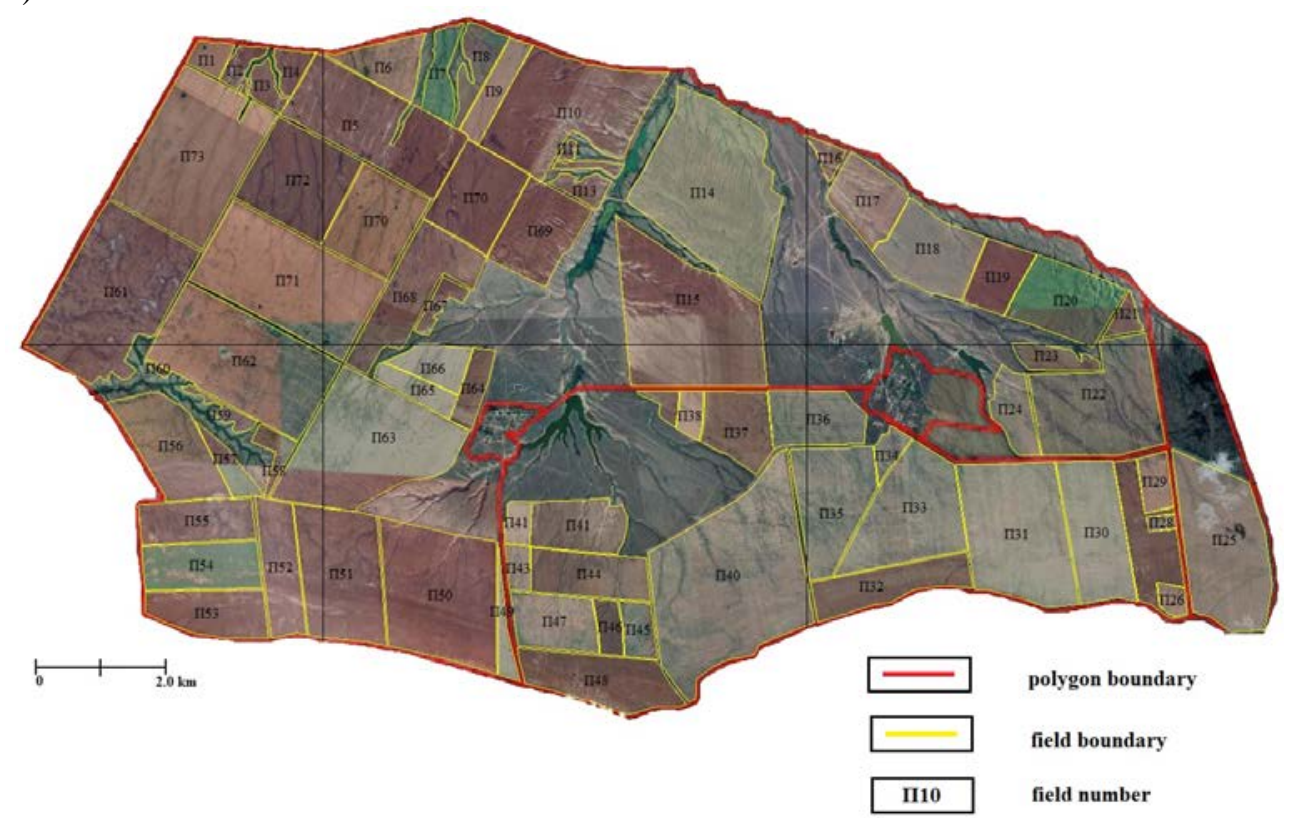

Fig. 1. Map of arable land use within the boundaries of Sovetsky settlement of Oktyabrsky municipal district

The linear erosion advancing is quite well seen by aerospace imagery. A good example is a land plot with a cadastral number 34:21:040003:67 and an area of 137,2 hectares, which is characterized by a high degree of the territory blurring, degradation of soil cover, 
which led to losing of humus and removing of salt marshes into the upper layers of the soil (Fig. 2).

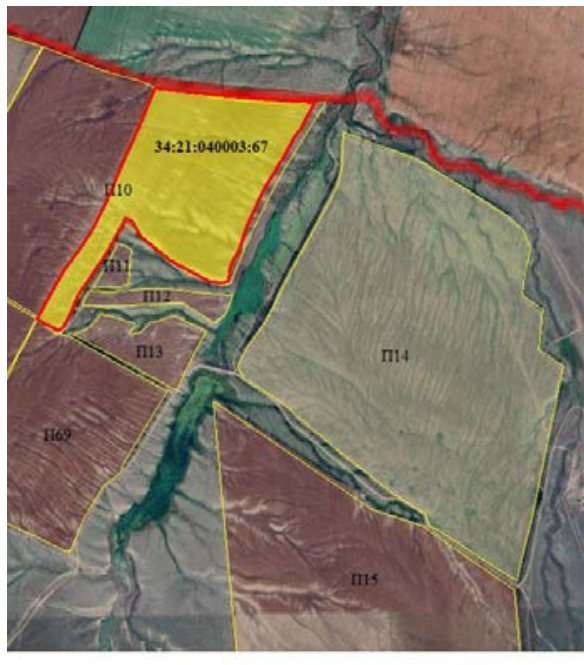

П10 arable land border

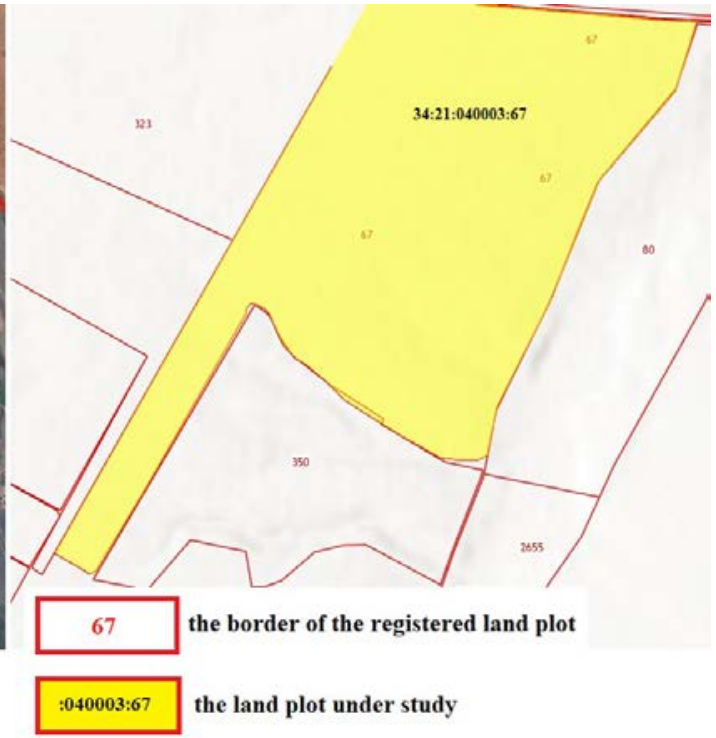

Fig. 2. Plot layout 34:21:040003:67 on space survey image

The total ball-bonitet in the territory of the studied settlement is 51, which corresponds to the indicator - below the average. Natural factors, intensification of agricultural production, lack of erosion measures have impact on the development of erosion processes.

Modern methods allow obtaining spatial data on condition and basic characteristics of arable lands. The configuration of the land with an area of 137,2 hectares used for the production of agricultural products is incorrect. The maximum width of the plot is 938,28 meters; the maximum length is 1462,68 meters. The average slope angle is $1,69^{\circ}$. There are no field-protective forest plantations on the plot, the presence of which is aimed at preventing erosion advancing and increasing crop yields.

The methodology of aerospace research methods and geoinformation technologies allow identifying more accurately current use and condition of all groups of land. [10].

Geoinformation analysis provides to assess soil loss dynamics with high efficiency in the remote mode, identify land contours to be subject to erosion and specify their boundaries and areas. Such provision is required for development of a set of anti-erosion measures both for individual parts of the agricultural landscape and in general.

Modern computer methods combined with space imagery of the territory under study allows applying innovative research technologies within a shorter period of time $[11,12]$.

In this regard, cartographic and aerospace monitoring becomes the most important methodological and methodological techniques, allowing tracking changes in the state, structure, dynamics and development of agricultural landscapes, and they include several scientific areas - economics, forest sector, amelioration, land management and agricultural sciences. In the near future that combination will result in achieving a high level of differentiated land use, stimulating the growth of agricultural production and its preservation. 


\section{References}

1. V.N. Khlystun, Herald of the Russian Academy of Sciences, 89, 4, 325-332 (2019).

2. E.V. Denisova, V.A. Silova, IOP Conference Series: Earth and Environmental Science, 52062 (2019).

3. I.A. Mirtova, Yu.E. Patsyna "Assessing disturbed lands in Moscow region with the use of space imagery. Izvestiya vuzov "Geodesy and Aerophotosurveying" 3, 71-76 (2013).

4. X. Li, X. Liu, L. Yu, Aggregative model-based classifier ensemble for improving landuse/cover classification of Landsat TM Images, Int. Journ. of Remote Sens, 35, 14811495 (2014).

5. H. Erol, F.A. Akdeniz Per-field classification method based on mixture distribution models and an application to Landsat Thematic Mapper data, Int. Journ. of Remote Sens, 26, 1229-1244 (2005).

6. D.P. Roy, M.A. Wulder, T.R. Loveland, Landsat-8: Science and product vision for terrestrial global change research. Remote Sensing of Environment. 145, 154-172 (2014).

7. K.L. Lidin, M.G. Meerovich, E.A. Bulgakova, V.V. Vershinin, T.V. Papaskiri, (Espacios), 39, 1, 12 (2018).

8. J.S. Rawat, Kumar Manish. Monitoring land use/cover change using remote sensing and GIS techniques: A case study of Hawalbagh block, district Almora, Uttarakhand, India, The Egyptian Journ. of Remote Sensing and Space Science, 18, 1, 77-84 (2015).

9. A. Arshad, F. Shahab, Quantification of Land Transformation Using Remote Sensing and GIS Techniques, American Journ. of Geographic Information System, 1, 2, 17-28 (2012).

10. T.V. Papaskiri, A.E. Kasyanov, N.N. Alekseenko, V. N. Semochkin, E. P. Ananicheva, A.A. Shevchuk, The proceedings 2019th International Symposium on Earth Sciences: History, Contemporary Issues and Prospects, 012065 (2019).

11. V.V. Vershinin, A.A. Murasheva, V.A. Shirokova, A.O. Khutorova, D.A. Shapovalov, V.A. Tarbaev, International journal of environmental \& science education, 11(12), 5058-5069 (2016).

12. S. Adrian, The Valuation Journal, 9(1), 54-71 (2014). 